Vol 5 No 2 (2022) 263-273 P-ISSN 2620-295 E-ISSN 2747-0490

DOI: $1047467 /$ elmal.v5i2.788

\title{
Pengaruh Persepsi Konsumen, Labelisasi Halal dan Citra Merek Terhadap Keputusan Pembelian Produk Herbal Skincare SR12
}

\author{
Ade Lia, Ibdalsyah, Hilman Hakiem \\ Universitas Ibn Khaldun Bogor \\ adeliaa.2103@gmail.com, buyaibdalsyah@gmail.com, \\ hilman@fai.uika-bogor.ac.id
}

\begin{abstract}
This study aims to determine the effect of consumer perceptions, halal labeling and brand image on purchasing decisions, while the independent variables are consumer perceptions, halal labeling and brand image. The data in this study were collected through questionnaires distributed to consumers who had purchased and used SR12 herbal skincare products in Bogor. The research method used is quantitative. The population in this study were consumers of SR12 herbal skincare products. With the data collected amounted to 100 respondents. The data analysis tool used in this study used multiple linear regression. The results of this study indicate that the variables of consumer perception, halal labeling and brand image have a positive and significant effect on purchasing decisions for sr12 herbal skincare products.
\end{abstract}

Keywords: Consumer Perception, Halal Labeling, Brand Image and Purchase Decision

\section{ABSTRAK}

Penelitian ini bertujuan untuk mengetahui pengaruh persepsi konsumen, labelisasi halal dan citra merek terhadap keputusan pembelian, sedangkan variabel independennya adalah persepsi konsumen, labelisasi halal dan citra merek. Data dalam penelitian ini dikumpulkan melalui kuisioner yang disebar kepada konsumen yang pernah membeli dan menggunakan produk herbal skincare SR12 di Bogor. Metode penelitian yang digunakan adalah kuantitatif. Populasi dalam penelitian ini yaitu konsumen produk herbal skincare SR12. Dengan data yang terkumpul berjumlah 100 responden. Alat analisis data yang digunakan dalam penelitian ini menggunakan regresi linier berganda. Hasil penelitian ini menunjukkan bahwa variabel persepsi konsumen, labelisasi halal dan citra merek berpengaruh positif dan signifikan terhadap keputusan pembelian produk herbal skincare sr12.

Kata Kunci : Persepsi Konsumen, Labelisasi Halal, Citra Merek dan Keputusan Pembelian 


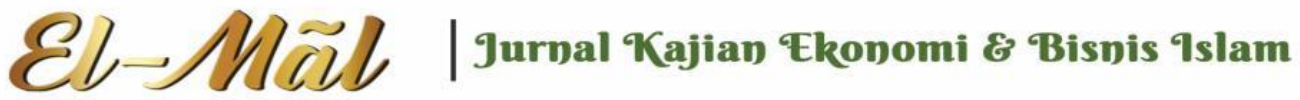

\section{Vol 5 No 2 (2022) 263-273 P-ISSN 2620-295 E-ISSN 2747-0490 DOI: $1047467 /$ elmal.v5i2.788}

\section{PENDAHULUAN}

Kosmetik merupakan salah satu produk kecantikan halal yang sedang berkembang di Indonesia. Saat ini pemakaian kosmetik hampir menjadi kebutuhan primer bagi para wanita. Adanya peluang pada industri kosmetik mendorong berbagai produsen kosmetik berlabel halal untuk melakukan inovasi. Hal tersebut agar produsen kosmetik berlabel halal dapat memenuhi kebutuhan konsumen.

Pada saat konsumen ingin memutuskan membeli suatu produk, sebenarnya mereka memiliki berbagai alasan tertentu dan ada juga yang tanpa alasan. Hal ini disebabkan karena begitu banyaknya produk kosmetik yang beranekaragam, mulai dari yang terdaftar BPOM (Badan Pengawas Obat dan Makanan) sampai yang tidak terdaftar ВРОM. Tindakan seseorang sesungguhnya dipengaruhi oleh persepsinya terhadap situasi saat itu. Namun persepsi tiap-tiap individu berbeda, walaupun berada dalam situasi yang sama. Hal tersebut terjadi karena kondisi lingkungan sekitar dan kondisi masing-masing individu.

Menurut Kolter (dalam Fauzan, 2021) mendefinisikan bahwa "persepsi merupakan proses yang digunakan oleh konsumen untuk memilih, mengorganisasikan dan menginterprestasikan masukan-masukan informasi guna menciptakan gambaran dunia yang memiliki arti". Informasi yang dimaksud dapat diartikan sebagai segala sesuatu yang masuk dan menciptakan sensasi terhadap seseorang, dapat berupa produk, kemasan, merek maupun iklan.

Menyadari bahwa indonesia sebagai negara yang mayoritas penduduknya muslim, maka kebutuhan akan jaminan kehalalan pada produk kosmetik sangatlah penting. Bagi umat muslim, kehalalan dari suatu produk adalah suatu hal yang penting dan utama. Hal pertama yang harus diteliti sebelum memilih dan memutuskan untuk membeli suatu produk adalah kehalalannya. Suatu produk bisa jadi memberikan manfaat positif bagi tubuh kita. Namun, ketika produk tersebut mengandung bahan-bahan yang tidak halal, maka pilihan terbaik adalah menghindari penggunaan produk tersebut.

Tidak terkecuali kosmetik. Sekalipun kosmetik adalah produk yang digunakan anggota tubuh bagian luar, namun sebagai muslim yang baik tetaplah harus 


\section{Vol 5 No 2 (2022) 263-273 P-ISSN 2620-295 E-ISSN 2747-0490 DOI: $1047467 /$ elmal.v5i2.788}

mempertimbangkan kehalalannya. Karena beberapa bahan yang digunakan untuk memproduksi kosmetik disinyalir tidak halal atau diragukan kehalalannya. Hal tersebut dapat dilihat dari beranekaragam produk kosmetik dipasaran nyatanya masih banyak yang belum jelas kehalalannya.

Menurut Sahir, dkk (2016) label halal adalah jaminan yang diberikan oleh suatu lembaga yang berwenang seperti lembaga pengkajian pangan obat-obatan dan kosmetika Majelis Ulama Indonesia (LPPOM-MUI) untuk memastikan bahwa produk tersebut sudah lolos pengujian kehalalan sesuai syariat islam. Pencantuman label halal bertujuan agar konsumen mendapatkan perlindungan kehalalan dan kenyamanan atas pemakaian produk tersebut.

Label halal dapat diperoleh setelah mendapatkan sertifikat halal. Sertifikat halal merupakan dokumen yang diterbitkan berdasarkan fatwa tertulis Majelis Ulama Indonesia (MUI) yang menyatakan kehalalan suatu produk sesuai dengan syari'at islam. Oleh karena itu, saat ini labelisasi halal sangat penting, karena untuk memastikan bahwa produk tersebut aman untuk digunakan baik dalam jangka pendek maupun jangka panjang. Serta menjadi alasan bagi konsumen dalam keputusan pembelian produk kosmetik halal.

Selain mengedepankan akan jaminan halal dan kesehatan, juga terdapat citra merek atau brand image yang membuatnya menjadi unik. Menurut Kolter dan Amstrong (dalam Anang, 2019) "Citra merek merupakan seperangkat keyakinan konsumen mengenai merek tertentu". Hal tersebut merupakan persepsi konsumen terhadap merek secara menyeluruh yang dibentuk oleh informasi yang diterima serta pengalaman konsumen atas merek tersebut. Ketika konsumen ditanya perihal citra merek, mereka akan mengungkapkan kesan dan keyakinan terhadap merek tertentu. Citra merek mempunyai peran yang penting dalam mempengaruhi keputusan pembelian. Konsumen yang memiliki sikap positif terhadap merek cenderung memilih merek tersebut dalam pembelian.

Didalam merek suatu produk terkandung janji perusahaan kepada konsumen untuk memberikan manfaat, keistimewaan dan layanan tertentu. Merek sangat bernilai karena dapat mempengaruhi persepsi konsumen. Merek yang baik dapat memberikan dampak positif terhadap konsumen yang mengarah pada sikap konsumen yang menguntungkan dan membawa kinerja penjualan serta keuangan yang lebih baik bagi perusahaan.

Dalam penelitian ini bertujuan untuk mengetahui pengaruh persepsi konsumen, labelisasi halal dan citra merek terhadap keputusan pembelian produk herbal skincare SR12 pada konsumen di era saat ini.

\section{TINJAUAN LITERATUR}

\section{Persepsi Konsumen}




\section{Vol 5 No 2 (2022) 263-273 P-ISSN 2620-295 E-ISSN 2747-0490 DOI: $1047467 /$ elmal.v5i2.788}

Menurut pendapat Anang dalam buku perilaku konsumen (sikap dan pemasaran) (2018:80) mendefinisikan bahwa persepsi konsumen adalah suatu proses yang membuat seseorang memilih, mengorganisasikan, dan menginterpretasikan rangsangan-rangsangan yang diterima menjadi suatu gambaran yang berarti dan lengkap tentang dunianya.

Faktor-faktor yang mempengaruhi persepsi konsumen menurut Anang (2018) diantaranya:

a. Faktor Individu, yaitu karakteristik konsumen yang muncul dari dalam diri konsumen. Termasuk proses di dalamnya bukan hanya pada panca indera, melainkan juga pada proses pengalaman yang serupa dan dorongan utama serta harapan dari individu.

b. Faktor Stimulus, yaitu karakteristik secara fisik seperti ukuran, berat, warna dan bentuk. Tampilan suatu produk, baik kemasan maupun karakteristik akan mampu menciptakan satu persepsi mengenai produk yang dilihatnya.

\section{Labelisasi Halal}

Menurut Zulham (2018) labelisasi halal merupakan perizinan pemasangan kata "HALAL" pada kemasan produk dari suatu perusahaan oleh Badan POM. Izin pencantuman label halal pada kemasan produk kosmetik yang dikeluarkan oleh Badan POM didasarkan rekomendasi MUI dalam bentuk sertifikat halal MUI. Sertifikat halal MUI dikeluarkan oleh MUI berdasarkan hasil pemeriksaan LPPOM-MUI terhadap produk yang bersangkutan.

Pada dasarnya, pengaturan penggunaan produk halal di Indonesia, memiliki dua hal yang saling berkaitan yaitu sertifikasi halal dan labelisasi halal. Kedua hal tersebut merupakan kegiatan yang berbeda tetapi memiliki keterkaitan satu sama lain. Sertifikasi halal merupakan fatwa tertulis MUI yang menyatakan kehalalan suatu produk sesuai syariat islam melalui pemeriksaan yang terperinci oleh LPPOM-MUI. Sertifikat halal ini sebagai syarat untuk mendapatkan izin pencantuman label halal pada kemasan produk dari instansi pemerintah yang berwenang (Badan POM).

\section{Citra Merek}

Menurut Anang (2019) "Citra merek merupakan suatu persepsi yang muncul dibenak konsumen ketika mengingat suatu merek dari produk tertentu". Hal tersebut karena citra merek sangatlah penting bagi setiap produk yang akan dijual di pasar dan menjadi ciri khas antara produk satu dengan yang lainnya.

Menurut Kolter dan Amstrong (dalam Anang, 2019) merek adalah nama, istilah, tanda, lambang atau design, atau kombinasi dari semua ini yang 


\section{Vol 5 No 2 (2022) 263-273 P-ISSN 2620-295 E-ISSN 2747-0490 DOI: $1047467 /$ elmal.v5i2.788}

memperlihatkan identitas produk atau jasa dari satu penjual atau sekelompok penjual dan membedakan produk itu dari produk pesaing.

\section{Keputusan Pembelian}

Menurut Anang (2018) mendefinisikan bahwa keputusan membeli merupakan kegiatan pemecahan masalah yang dilakukan individu dalam pemilihan alternatif perilaku yang sesuai dari dua alternatif atau lebih dan dianggap sebagai tindakan yang paling tepat dalam membeli dengan terlebih dahulu memulai tahapan proses pengambilan keputusan.

Terdapat beberapa tahapan seorang konsumen dalam melakukan keputusan pembelian, diantaranya :

a. Pengenalan masalah, proses pembelian oleh konsumen diawali sejak pembeli mengenali kebutuhan atau masalah. Kebutuhan tersebut dapat ditimbulkan oleh rangsangan internal maupun eksternal.

b. Pencarian informasi, setelah konsumen terangsang kebutuhannya, konsumen akan terdorong untuk mencari informasi yang lebih banyak.

c. Evaluasi alternatif, evaluasi mencerminkan keyakinan dan sikap yang mempengaruhi perilaku pembelian mereka. Keyakinan merupakan gambaran pemikiran yang dianut seseorang tentang gambaran sesuatu. Keyakinan seseorang tentang produk atau merek mempengaruhi keputusan pembelian mereka.

d. Keputusan pembelian, setelah tahap-tahap di atas dilakukan, tahap selanjutnya yaitu pembeli menentukan pengambilan keputusan menyangkut jenis produk, bentuk produk, merek, penjual, kualitas dan sebagainya. Konsumen dapat mengambil beberapa sub keputusan meliputi merek, pemasok, jumlah, waktu pelaksanaan dan metode pembayaran.

e. Perilaku pasca pembelian, pemasar harus memperhatikan konsumen setelah melakukan pembelian produk. Setelah membeli suatu produk, konsumen akan mengalami beberapa tingkat kepuasan atau tidak ada kepuasan. Konsumen akan membandingkan produk atau jasa yang telah ia beli, dengan produk atau jasa lain.

Adanya hubungan antara persepsi konsumen, labelisasi halal dan citra merek terhadap keputusan pembelian telah dibuktikan oleh beberapa penelitian sebelumnya. Dalam penelitian yang dilakukan oleh Adhitya Nurfaizal (2021), dengan judul “Pengaruh persepsi konsumen, gaya hidup dan citra merek terhadap keputusan pembelian wifi indihome di kelurahan kalidoni kota pelambang". Tujuan dari penelitian ini adalah untuk mengetahui apakah ada pengaruh persepsi konsumen, gaya hidup dan citra merek terhadap keputusan pembelian wifi indihome dikelurahan kalidoni kota pelambang. Teknik analisis yang digunakan dalam penelitian ini 


\section{Vol 5 No 2 (2022) 263-273 P-ISSN 2620-295 E-ISSN 2747-0490 DOI: $1047467 /$ elmal.v5i2.788}

adalah analisis regresi linier berganda yang diolah menggunakan program SPSS. Hasil penelitian ini menunjukkan bahwa ada pengaruh secara simultan dari persepsi konsumen, gaya hidup dan citra merek terhadap keputusan pembelian wifi indihome di kelurahan kalidoni.

Rahmawati Rahman (2018), dengan judul "Pengaruh Labelisasi Halal dan Citra Merek terhadap Keputusan Pembelian Produk Ponds White Beauty di Kecamatan Tamalate Kota Makasar (Ditinjau dari Perspektif Ekonomi Islam)". Tujuan dari penelitian ini untuk mengetahui apakah labelisasi halal dan citra merek berpengaruh positif dan signifikan terhadap keputusan pembelian produk kosmetik ponds white beauty di kecamatan Tamalate kota Makassar. Penelitian ini menggunakan metode kuantitatif dengan pendekatan syar'i dan deskriptif. Hasil penelitian ini mengungkapkan bahwa terdapat pengaruh positif dan signifikan labelisasi halal dan citra merek terhadap keputusan pembelian.

\section{METODE PENELITIAN}

Metode yang digunakan dalam penelitian ini adalah penelitian kuantitatif, karena data penelitian berupa angka-angka dan analisisnya menggunakan statistika.

Menurut Sugiyono (2013:8) mendefinisikan metode penelitian kuantitatif sebagai metode penelitian yang berlandaskan pada filsafat positivisme, digunakan untuk meneliti pada populasi atau sampel tertentu, pengumpulan data menggunakaninstrumen penelitian, analisis data bersifat kuantitatif/statistik, dengan tujuan untuk menguji hipotesis yang telah ditetapkan.

\section{Populasi dan Sampel}

Populasi dalam penelitian ini adalah konsumen herbal skincare SR12 yang pernah membeli dan menggunakan produk SR12.

Dalam penelitian ini pengambilan sampel dengan menggunakan teknik nonprobability sampling, yaitu teknik pengambilan sampel yang tidak memberi peluang atau kesempatan sama bagi setiap unsur atau anggota populasi untuk dipilih menjadi sampel. Teknik sampel dalam penelitian ini menggunakan sampling kuota, yaitu teknik untuk menentukan sampel dari populasi yang mempunyai ciri-ciri tertentu sampai julah (kuota) yang diinginkan (Sugiyono, 2013). Jumlah sampel yang butuhkan dalam penelitian ini yaitu sebanyak 100 responden.

\section{Tempat dan Waktu Penelitian}




\section{El-Mäl | Jurral Kajian Ekonomi \& Bispis slam}

\section{Vol 5 No 2 (2022) 263-273 P-ISSN 2620-295 E-ISSN 2747-0490 DOI: $1047467 /$ elmal.v5i2.788}

Penelitian ini dilaksanakan di Manjadda Store SR12 Distributor Herbal Skincare Parung Bogor.

Dalam penelitian ini waktu yang digunakan peneliti dilaksanakan sejak dikeluarkannya surat izin penelitian dalam kurun waktu kurang lebih 2 (dua) bulan, 1 bulan dilakukan untuk pengumpulan data dan 1 bulan untuk pengolahan data yang meliputi penyajian dalam bentuk skripsi dan proses bimbingan berlangsung.

\section{Teknik Pengumpulan Data}

Teknik pengumpulan data yang digunakan dalam penelitian ini adalah kuisioner dengan menggunakan skala likert untuk mengukur sikap, pendapat, dan persepsi seseorang atau sekelompok orang tentang fenomena sosial. jawaban dari setiap item instrumen yang menggunakan skala likert mempunyai gradasi dari sangat positif sampai sangat negatif.

\section{Teknik Analisis Data}

Analisis data yang digunakan dalam penelitian ini adalah kuantitatif deskriptif. Yang diolah dengan menggunakan bantuan SPSS versi 25. Melalui uji asumsi klasik, analisis regresi linier berganda dan uji hipotesis.

\section{Definisi Variabel}

a. Variabel Independen (bebas) dalam penelitian ini adalah persepsi konsumen $\left(\mathrm{X}_{1}\right)$, labelisasi halal $\left(\mathrm{X}_{2}\right)$ dan citra merek $\left(\mathrm{X}_{3}\right)$.

b. Variabel Dependen (terikat) dalam penelitian ini adalah keputusan pembelian (Y).

\section{Hasil dan Pembahasan}

\section{Hasil Uji t \\ Coefficients $^{\mathrm{a}}$}

\begin{tabular}{|c|c|c|c|c|c|c|}
\hline \multirow{2}{*}{\multicolumn{2}{|c|}{ Model }} & \multicolumn{2}{|c|}{$\begin{array}{l}\text { Unstandardized } \\
\text { Coefficients }\end{array}$} & \multirow{2}{*}{$\begin{array}{c}\text { Standardize } \\
\text { d } \\
\text { Coefficients }\end{array}$} & \multirow[b]{2}{*}{$\mathrm{T}$} & \multirow[b]{2}{*}{ Sig. } \\
\hline & & B & Std. Error & & & \\
\hline \multirow[t]{4}{*}{1} & (Constant) & -1.672 & 3.833 & & -.436 & .664 \\
\hline & $\begin{array}{l}\text { persepsi } \\
\text { konsumen }\end{array}$ & .474 & .119 & .332 & 3.998 & .000 \\
\hline & labelisasi halal & .616 & .115 & .388 & 5.358 & .000 \\
\hline & citra merek & .177 & .058 & .251 & 3.051 & .003 \\
\hline
\end{tabular}

Sumber: Data diolah pada SPSS 25 (2021) 


\section{Vol 5 No 2 (2022) 263-273 P-ISSN 2620-295 E-ISSN 2747-0490 DOI: $1047467 /$ elmal.v5i2.788}

Berdasarkan tabel diatas, perhitungan analisis uji t adalah sebagai berikut:

1) Diketahui nilai sig. untuk pengaruh $\mathrm{X} 1$ terhadap $Y$ sebesar $0,000<0,05$ sehingga dapat disimpulkan bahwa Ho ditolak dan Ha diterima, yang berarti persepsi konsumen (X1) berpengaruh signifikan terhadap keputusan pembelian (Y).

2) Diketahui nilai sig. untuk pengaruh $X 2$ terhadap $Y$ sebesar $0,000<0,05$ sehingga dapat disimpulkan bahwa Ho ditolak dan Ha diterima, yang berarti labelisasi halal (X2) berpengaruh signifikan terhadap keputusan pembelian (Y).

3) Diketahui nilai sig. untuk pengaruh 31 terhadap Y sebesar 0,003 $<0,05$ sehingga dapat disimpulkan bahwa Ho ditolak dan Ha diterima, yang berarti citra merek (X3) berpengaruh signifikan terhadap keputusan pembelian.

\section{Hasil Uji F}

ANOVA $^{\mathrm{a}}$

\begin{tabular}{|c|c|c|c|c|c|c|}
\hline \multicolumn{2}{|c|}{ Model } & \multirow{2}{*}{$\begin{array}{l}\begin{array}{c}\text { Sum of } \\
\text { Squares }\end{array} \\
1805.462\end{array}$} & \multirow{2}{*}{$\frac{\text { Df }}{3}$} & \multirow{2}{*}{\begin{tabular}{l} 
Mean \\
\multicolumn{1}{c}{$\begin{array}{l}\text { Square } \\
601.821\end{array}$}
\end{tabular}} & \multirow{2}{*}{$\frac{F}{42.465}$} & \multirow{2}{*}{$\begin{array}{l}\text { Sig. } \\
.000^{\mathrm{b}}\end{array}$} \\
\hline 1 & $\begin{array}{l}\text { Regressio } \\
\mathrm{n}\end{array}$ & & & & & \\
\hline & Residual & 1360.538 & 96 & 14.172 & & \\
\hline & Total & 3166.000 & 99 & & & \\
\hline
\end{tabular}

Sumber: Data diolah pada SPSS 25 (2021)

Berdasarkan hasil yang terdapat pada tabel 4.11 diatas, diketahui secara simultan pada variabel independen yang terdiri dari persepsi konsumen, labelisasi halal dan citra merek mempunyai nilai signifikansinya sebesar 0,000 $<0,05$. Sehingga dapat disimpulkan bahwa Ho ditolak dan Ha diterima. Artinya variabel persepsi konsumen $\left(\mathrm{X}_{1}\right)$, labelisasi halal $\left(\mathrm{X}_{2}\right)$, dan citra merek $\left(\mathrm{X}_{3}\right)$ berpengaruh positif dan signifikan terhadap keputusan pembelian (Y).

Berdasarkan data primer atau kuisioner yang telah peneliti olah dengan bantuan SPSS versi 25, maka peneliti memperoleh pembahasan sebagai berikut:

\section{Pengaruh Persepsi Konsumen terhadap Keputusan Pembelian Produk} Herbal Skincare SR12

Hasil penelitian menunjukkan bahwa persepsi konsumen berpengaruh secara signifikan terhadap keputusan pembelian produk herbal skincare SR12. Hasil uji statistik menunjukkan nilai signifikansi sebesar 0,000 $<0,05$.

Dalam penelitian ini dapat dikatakan bahwa persepsi konsumen mampu mendorong konsumen untuk melakukan pembelian. Artinya adanya informasi 


\section{Vol 5 No 2 (2022) 263-273 P-ISSN 2620-295 E-ISSN 2747-0490 DOI: $1047467 /$ elmal.v5i2.788}

yang baik atau pengalaman seseorang, sehingga persepsi konsumen mampu mendorong keputusan pembelian pada produk SR12.

Penelitian ini didukung oleh Adhitya Nurfaizal (2021) yang menyatakan bahwa persepsi konsumen memiliki pengaruh yang signifikan terhadap keputusan pembelian dengan nilai signifikansi sebesar 0,019<0,05. Yang artinya jika persepsi yang baik dirasakan oleh konsumen, maka keputusan pembelian akan meningkat.

\section{Pengaruh Labelisasi Halal terhadap Keputusan Pembelian Produk Herbal Skincare SR12}

Hasil penelitian menunjukkan bahwa labelisasi halal berpengaruh secara signifikan terhadap keputusan pembelian produk herbal skincare SR12. Hasil uji statistik menunjukkan bahwa signifikansi sebesar 0,000 $<0,05$.

Dalam penelitian ini dapat dikatakan bahwa labelisasi halal mampu mendorong konsumen untuk melakukan pembelian pada produk herbal skincare SR12.

Penelitian ini didukung oleh Dinda Astuty (2021) yang menyatakan bahwa labelisasi halal berpengaruh secara signifikan terhadap keputusan pembelian kosmetik purbasari di wilayah binjai dengan nilai signifikansi sebesar 0,000 < 0,05 .

\section{Pengaruh Citra Merek terhadap Keputusan Pembelian Produk Herbal Skincare SR12}

Hasil penelitian menunjukkan bahwa citra merek berpengaruh secara signifikan terhadap keputusan pembelian produk herbal skincare SR12. Hasil uji statistik menunjukkan bahwa nilai signifikansi sebesar 0,003 $<0,05$.

Dalam penelitian ini berarti semakin baik citra merek yang diciptakan oleh perusahaan maka keputusan pembelian konsumen akan meningkat.

Penelitian ini didukung oleh Ninda Sulistyani 2020 yang menyatakan bahwa citra merek memiliki pengaruh positif dan signifikan terhadap rencana keputusan pembelian dengan signifikansi sebesar 0,002 <0,05.

\section{Pengaruh Persepsi Konsumen, Labelisasi Halal dan Citra Merek terhadap Keputusan Pembelian Produk Herbal Skincare SR12}

Hasil penelitian menunjukkan bahwa persepsi konsumen, labelisasi halal dan citra merek berpengaruh secara signifikan terhadap keputusan pembelian produk herbal skincare SR12. Hasil uji statistik menunjukkan nilai signifikan sebesar 0,000 $<0,05$ pada variabel persepsi konsumen dan labelisasi halal. Sementara pada variabel citra merek dengan nilai signifikan sebesar 0,003 $<0,05$.

Hasil penelitian ini didukung oleh penelitian terdahulu yang diteliti oleh Rahmawati Rahman (2018) dengan judul "Pengaruh Labelisasi Halal dan Citra 


\section{Vol 5 No 2 (2022) 263-273 P-ISSN 2620-295 E-ISSN 2747-0490 DOI: $1047467 /$ elmal.v5i2.788}

Merek terhadap Keputusan Pembelian Produk Ponds White Beauty di Kecamatan Tamalate Kota Makasar (Ditinjau dari Perspektif Ekonomi Islam)". Dan penelitian yang dilakukan oleh Gita Sukmawati Putri dan Aniek Wahyuati (2015) dengan judul "Pengaruh persepsi konsumen, kualitas pelayanan dan citra merek terhadap loyalitas". Dimana pada hasil penelitian tersebut membuktikan bahwa variabel persepsi konsumen, labelisasi halal dan citra merek mempunyai pengaruh positif dan signifikan terhadap keputusan pembelian.

\section{KESIMPULAN}

Kesimpulan dari hasil penelitian mengenai pengaruh persepsi konsumen, labelisasi halal dan citra merek terhadap keputusan pembelian produk herbal skincare SR12 sebagai berikut:

1. Dalam penelitian ini variabel persepsi konsumen memiliki pengaruh secara signifikan terhadap keputusan pembelian produk herbal skincare SR12. Hal ini dibuktikan oleh nilai signifikansi yang diperoleh sebesar 0,000. Dimana 0,000 $<0,05$ yang berarti Ho ditolak dan Ha diterima.

2. Dalam penelitian ini variabel labelisasi halal memiliki pengaruh secara signifikan terhadap keputusan pembelian produk herbal skincare SR12. Hal ini dibuktikan oleh nilai signifikansi yang diperoleh sebesar 0,000. Dimana 0,000 < 0,05 yang artinya Ho ditolak dan Ha diterima.

3. Dalam penelitian ini variabel citra merek memiliki pengaruh secara signifikan terhadap keputusan pembelian produk herbal skincare SR12. Hal ini dibuktikan oleh nilai signifikansi yang diperoleh sebesar 0,003. Dimana 0,003 $<0,05$ yang artinya Ho ditolak dan Ha diterima.

4. Dalam penelitian ini variabel persepsi konsumen, labelisasi halal dan citra merek secara simultan memiliki pengaruh secara signifikan terhadap keputusan pembelian produk herbal skincare SR12. Hal ini dibuktikan oleh nilai signifikansi variabel persepsi konsumen dan labelisasi halal sebesar 0,000 $<0,05$ dan variabel citra merek sebesar 0,003 $<0,05$ yang artinya Ho ditolak dan Ha diterima.

\section{DAFTAR PUSTAKA}

Astuty, D. (2021). Pengaruh Labelisasi Halal, Kesadaran Halal, Harga Produk dan Citra Merek Terhadap Keputusan Pembelian Produk Kosmetik Merek Purbasari (Studi kasus konsumen wilayah binjai). Kumpulan Karya Ilmiah Mahasiswa Fakultas Sosial Sains, 1 (01).

Fauzan, Hemmy., dan Putra, Irhamsyah. (2021). Dinamika Konsumen Dalam Pemilihan Pembiayaan Rumah Skema Syariah. Bandung: CV Media Sains Indonesia. 


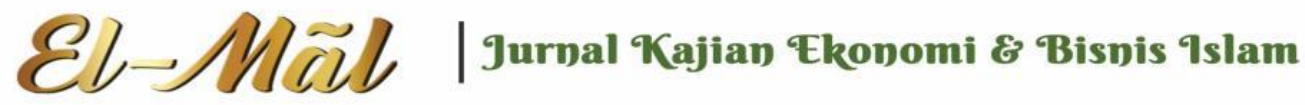

\section{Vol 5 No 2 (2022) 263-273 P-ISSN 2620-295 E-ISSN 2747-0490 \\ DOI: 1047467/elmal.v5i2.788}

Firmansyah, A. (2018). Perilaku Konsumen (Sikap dan Pemasaran). Yogyakarta: Penerbit Deepublish.

Firmansyah, A. (2019). Pemasaran Produk dan Merek (Planning \& Strategy). Surabaya: CV. Qiara Media.

Nurfaizal, A. (2021). Pengaruh persepsi konsumen, gaya hidup dan citra merek terhadap keputusan pembelian wifi indihome di kelurahan kalidoni kota Pelambang (Doctoral dissertation, 021008 Universitas Tridinanti Palembang).

Putri, G. S., \& Wahyuati, Aniek. (2015). Pengaruh persepsi konsumen, kualitas pelayanan dan citra merek terhadap loyalitas. Jurnal Ilmu dan Riset Manajemen (JIRM), 4(11).

Rahman, R. (2018). Pengaruh Labelisasi Halal dan Citra Merek terhadap Keputusan Pembelian Produk Ponds White Beauty di Kecamatan Tamalate Kota Makasar (Ditinjau dari Perspektif Ekonomi Islam) (Doctoral dissertation, Universitas Islam Negeri Alauddin Makassar).

Sahir, S. H., Ramadhani, A., \& Tarigan, E. D. S. (2016). Pengaruh gaya hidup, label halal dan harga terhadap keputusan pembelian kosmetik wardah pada mahasiswa program studi manajemen fakultas ekonomi universitas medan area medan. JKBM (JURNAL KONSEP BISNIS DAN MANAJEMEN), 3(1).

Sugiyono. (2013). Metode penelitian kuantitatif, kualitatif dan R\&D. Bandung: Alfabeta, cv

Sulistyani, N. (2020). Pengaruh labelisasi halal dan citra merek terhadap rencana keputusan pembelian konsumen di salwa bakery trenggalek.

Zulham, S. (2018). Peran negara dalam perlindungan konsumen muslim terhadap produk halal. Jakarta: Kencana 